\title{
ANALISIS UPAYA PEMERINTAH MEMINIMALISIR RISIKO GAGAL BAYAR DALAM PEMBERIAN PINJAMAN KEPADA BUMN
}

\section{(Analysis of Government Efforts to Minimize The Risk of Failure to Pay in Providing Loans to State-Owned Enterprises)}

\author{
Xavier Nugraha, Patricia Inge Felany, dan M.Imron Rosyadi \\ Mahasiswa Fakultas Hukum Universitas Airlangga \\ Jl. Dharmawangsa Dalam Selatan, Airlangga, Kec. Gubeng - 60281 \\ e-mail: xavier.nugraha-2015@fh.unair.ac.id
}

\begin{abstract}
Abstrak
Salah satu bentuk kegiatan yang dilakukan pemerintah untuk mengelola uang negara adalah dengan melakukan pinjaman kepada BUMN. Hal ini dilakukan untuk melaksanakan kegiatan pembangunan nasional terutama percepatan pembangunan infrastruktur. Meskipun pinjaman tersebut untuk kegiatan BUMN, namun tetap harus sesuai dengan prinsip good governance. Perlu ada upaya pemerintah untuk meminimalisir risiko gagal bayar yang muncul dalam pemberian pinjaman kepada BUMN. Berdasarkan latar belakang tersebut, rumusan masalah dalam penelitian ini adalah 1) Apa upaya preventif terhadap risiko gagal bayar dalam pemberian pinjaman kepada BUMN? 2) Apa upaya represif terhadap risiko gagal bayar dalam pemberian pinjaman kepada BUMN? Penelitian ini adalah penelitian hukum. Pendekatan yang digunakan adalah pendekatan perundang-undangan dan pendekatan konseptual. Berdasarkan penelitian ini, ditemukan bahwa 1) Upaya preventif yang dapat dilakukan oleh pemerintah berupa penerapan sikap kehati-hatian dalam setiap tahap pelaksanaan pemberian pinjaman serta adanya penilaian, pengawasan, serta evaluasi terhadap pelaksanaan pemberian pinjaman kepada BUMN dan 2) Upaya represif yang dapat dilakukan berupa pengenaan denda administrasi serta penerapan sanksi pidana.
\end{abstract}

Kata Kunci: BUMN, Utang, Gagal Bayar, Upaya Preventif, Upaya Represif.

\begin{abstract}
One form of activity carried out by the government to manage state money is by making loans to SOEs. This Loan is to carry out national development, especially to accelerated infrastructure development. Although the loan is for SOEs activities, there must be some efforts to minimize the risk of default that arises in granting loans to SOEs. Based on this background, the formulation of the problem in this study is 1) What is the preventive effort against the risk of default in lending to SOEs? and 2) What is the repressive effort to the risk of default in lending to SOEs? Based on this research, it was found that 1) Preventive efforts that can be carried out by the government in the form of the application of prudential attitudes in each stage of the implementation of lending as well as the authority to conduct assessments, supervision, and evaluation 2) Repressive efforts in the form of imposition administrative fines and application of criminal sanctions. Keywords: SOEs, Debt, Failure to Pay, Preventive Efforts, Repressive Efforts
\end{abstract} Keywords : SOEs, Debt, Failure to Pay, Preventive Efforts, Repressive Efforts. 


\section{A. Pendahuluan}

Konstitusi Indonesia telah menegaskan kedudukan Indonesia sebagai suatu negara hukum (rechtsstaat) yang tertuang di dalam Pasal 1 UndangUndang Dasar Negara Republik Indonesia 1945. A.V. Dicey menyebut Negara Hukum sendiri dengan istilah "The Rule of Law" dengan menguraikan adanya tiga ciri penting dalam setiap Negara Hukum, yaitu: ${ }^{1}$

\section{Supremacy of law}

2. Equality before the law

3. Due Process of Law.

Sedangkan menurut Sri Soemantri sebuah negara termasuk dalam golongan negara hukum dengan mengandung beberapa unsur penting, yakni: ${ }^{2}$

1. Bahwa pemerintahan dalam menjalankan tugas dan kewajibannya harus berdasarkan hukum atau perat 2

2. Peraturan perundang-undangan;

3. Adanya jaminan terhadap hak-hak asasi manusia (warganya);

4. Adanya pembagian kekuasaan dalam Negara;

5. Adanya pengawasan dari badan-badan peradilan (rechterlijke controle).

Indonesia bukan hanya negara hukum, namun negara hukum berdasarkan konstitusi, artinya, Indonesia bukan hanya negara berdasarkan hukum namun negara berdasarkan konstitusi. Berarti, Indonesia tidak hanya wajib memenuhi prinsip negara hukum, namun juga memenuhi prinsip-prinsip di dalam konstitusi Indonesia. Salah satu bentuk irisan, antara Indonesia sebagai negara hukum berdasarkan konstitusi dapat dilihat pada alinea IV pembukaan Undang-Undang Dasar Negara Republik Indonesia 1945 yang menyatakan bahwasanya tujuan negara Indonesia ialah untuk melindungi segenap bangsa Indonesia dan seluruh tumpah darah Indonesia, mewujudkan kesejahteraan umum, mencerdaskan kehidupan bangsa, dan ikut melaksanakan ketertiban dunia yang berdasarkan kemerdekaan, perdamaian abadi, dan keadilan sosial.

Dalam rangka mengejawantahkan tujuan negara memajukan kesejahteraan umum, pembentuk Undang-Undang Dasar Tahun 1945 merumuskan politik hukum perekonomian nasional dalam Pasal 33 UUD Tahun 1945, Bab XIV mengenai Perekonomian Nasional dan Kesejahteraan Sosial sebagai berikut:

1. Perekonomian disusun sebagai usaha bersama berdasar atas asas kekeluargaan.

2. Cabang-cabang produksi yang penting bagi negara dan yang menguasai hajat hidup orang banyak dikuasai oleh negara.

3. Bumi dan air dan kekayaan alam yang terkandung di dalamnya dikuasai oleh

1 A.V.Dicey, Introduction to the Study of the Law of the Constitution, Tenth Edition (London: The Macmillan Press,1979), hlm. 406.

2 Fakhurohman, Dian Aminudin dan Sirajudin, Memahami Keberadaan Mahkamah Konstitusi di Indonesia (Bandung: Citra Aditya Bakti, 2004), hlm. 7. 
negara dan dipergunakan untuk sebesar-besarnya kemakmuran rakyat.

4. Perekonomian nasional diselenggarakan berdasar atas demokrasi ekonomi dengan prinsip kebersamaan, efisiensi berkeadilan, berkelanjutan, berwawasan lingkungan, kemandirian, serta dengan menjaga keseimbangan kemajuan dan kesatuan ekonomi nasional.

5. Ketentuan lebih lanjut mengenai pelaksanaan pasal ini diatur dalam Undang-Undang.

Melihat Pasal 33 Undang-Undang Dasar Negara Republik Indonesia 1945 dan penjelasannya dapat dipahami bahwasanya arah perekonomian yang diselenggarakan di Indonesia berdasarkan demokrasi ekonomi atau sistem ekonomi kerakyatan, dimana sistem ekonomi kerakyatan adalah sebuah sistem perekonomian yang sangat menekankan pentingnya partisipasi seluruh anggota masyarakat dalam proses penyelenggaraan perekonomian. Sehubungan dengan itu, dalam sistem ekonomi kerakyatan, setiap anggota masyarakat tidak dapat hanya diperlakukan sebagai objek perekonomian. la adalah subjek perekonomian, yaitu yang memiliki hak untuk berpartisipasi secara langsung dalam proses penyelenggaraan perekonomian, serta dalam mengawasi berlangsungnya proses perekonomian tersebut. ${ }^{3}$

Dalam menciptakan kesejahteraan rakyat tersebut tentunya diperlukan anggaran yang jumlahnya cukup besar, sehingga pemerintah harus mampu membiayai segala kebutuhan pelaksanaan penyelenggaraan negara tersebut ${ }^{4}$. Hal ini bertujuan, agar negara dapat melaksanakan tanggung jawabnya dengan baik dalam rangka pencapaian tujuan bernegara sesuai amanah Alinea IV Pembukaan Undang-Undang Dasar Negara Republik Indonesia Tahun 1945. Dalam rangka melaksanakan tujuan tersebut, tentunya dibutuhkannya keterlibatan penyelenggara usaha seperti Badan Usaha Milik Negara / BUMN yang notabene merupakan salah satu perangkat negara yang memiliki peran besar untuk meningkatkan kesejahteraan rakyat. Hal ini disebabkan, karena BUMN dipercaya, sebagai instrumen riil untuk terciptanya demokrasi ekonomi yang notabene BUMN akan difungsikan sebagai "agent of development."5

Pendirian Badan Usaha Milik Negara oleh Pemerintah Indonesia mengandung dua tujuan utama, yaitu tujuan yang bersifat ekonomi dan tujuan yang bersifat sosial. ${ }^{6}$ Dalam tujuan yang bersifat ekonomi, BUMN dimaksudkan untuk mengelola sektor-sektor bisnis

3 Aminuddin Ilmar, Hak Mengusai Negara Dalam Privatisasi BUMN (Jakarta: Kharisma Putra Utama, 2012), hlm. 12.

4 Bohari, Hukum Anggaran Negara (Jakarta: Rajawali Press, 1995), hlm. 7.

5 Aminuddin Ilmar, Op.Cit., hlm. 72.

6 Rahayu Hartini, BUMN Persero, Konsep Keuangan Negara dan Hukum Kepailitan di Indonesia (Malang: Setara Press, 2017), hlm. 66. 
strategis agar tidak dikuasai pihakpihak tertentu. Bidang-bidang usaha yang menyangkut hajat hidup orang banyak, seperti perusahaan listrik, minyak dan gas bumi, sebagaimana diamanatkan dalam Pasal 33 UUD 1945, seyogyanya dikuasai oleh BUMN. Dengan adanya BUMN diharapkan dapat terjadi peningkatan kesejahteraan masyarakat, terutama masyarakat yang berada di sekitar lokasi BUMN. Tujuan BUMN yang bersifat sosial antara lain dapat dicapai melalui penciptaan lapangan kerja serta upaya untuk membangkitkan perekonomian lokal. Penciptaan lapangan kerja dicapai melalui perekrutan tenaga kerja oleh BUMN. Upaya untuk membangkitkan perekonomian lokal dapat dicapai dengan jalan mengikutsertakan masyarakat sebagai mitra kerja dalam mendukung kelancaran proses kegiatan usaha. Hal ini sejalan dengan kebijakan pemerintah untuk memberdayakan usaha kecil, menengah dan koperasi yang berada di sekitar lokasi BUMN.7 Yang artinya, peran penting BUMN bukan hanya diharapkan sebagai pengemban kepentingan dan pelayanan serta pemenuhan kebutuhan rakyat banyak, tetapi juga sebagai penyumbang terbesar dalam perekonomian nasional. 8 Sesuai pada Pasal 9 Undang-Undang Nomor 19 Tahun
2003 tentang BUMN, jenis BUMN terbagi menjadi 2, yakni Perusahaan Persero (Persero) dan Perusahaan Umum (Perum)/ Statutory public Corporation ${ }^{9}$, dimana sumber pendanaan BUMN dapat dilihat dalam Pasal 4 Undang-Undang Nomor 19 Tahun 2003 jo. Peraturan Pemerintah Nomor 44 Tahun 2005 tentang Tata Cara Penyertaan Dan Penatausahaan Modal Negara Pada Badan Usaha Milik Negara dan Perseroan terbatas pada Pasal 2 ayat (1) dinyatakan bahwa penyertaan modal negara kepada BUMN dan Perseroan Terbatas bersumber dari :

a. Anggaran Pendapatan dan Belanja Negara (APBN);

b. Kapitalisasi cadangan; dan/atau

c. Sumber lainnya.

Pada kenyataannya, pengumpulan penerimaan negara ternyata belum cukup optimal untuk menutup anggaran belanja Pemerintah yang lebih besar, terutama pendapatan pajak sebagai tulang punggung Anggaran Pembangunan dan Belanja Negara (APBN) ${ }^{10}$. Dalam rangka menghasilkan sebuah solusi

7 Nanang Yusroni dan Dumadi Tri Restiysnto, “Privatisasi Badan Usaha Milik Negara (BUMN), Eksistensi, Dan Kinerja Ekonomi Nasional Dalam Sistem Ekonomi Pasar," Jurnal Ekonomi dan Bisinis 3 (2007): 73.

8 Harsono, "Kerjasama antara Perusahaan Negara, Swasta, dan Koperasi dalam rangka Menyukseskan Pembangunan Ekonomi di Indonesia" (Pidato Pengukuhan dalam Penerimaan Jabatan Guru Besar Universitas Brawijaya, Malang, Indoensia, 1986, hlm. 2).

9 Ibrahim R." Landasan Filosofis dan Yuridis Keberadaan BUMN: Sebuah Tinjauan", Jurnal Hukum Bisnis 26 (2007): 8.

10 BPK RI, Jurnal Tata Kelola \& Akuntabilitas Keuangan Negara (Jakarta: BPHN Puslitbang, 2010), hlm. 24. 
konkrit, maka upaya yang diambil pemerintah untuk pembiayaan anggaran adalah melalui penarikan pinjaman. Pinjaman ini, umumnya terdiri dari dua sumber, yaitu: 11

1. Sumber pinjaman dari dalam negeri

2. Sumber pinjaman dari luar negeri

Sumber dana yang bersumber dari dua pinjaman tersebut oleh Pemerintah, nantinya akan diserahkan salah satunya kepada BUMN. ${ }^{12}$ Bagi BUMN dana tersebut dapat digunakan sebagai solusi untuk pembiayaan BUMN, sehingga dapat meningkatkan kinerja BUMN. Dikarenakan hubungan kontraknya berbasis pada perjanjian "pinjaman", maka BUMN sebagai pihak penerima pinjaman (debitor), wajib melakukan pembayaran kembali pemberian pinjaman tersebut sesuai dengan perjanjian yang telah disepakati dan ketentuan perundang-undangan yang berlaku. Berdasarkan hal tersebut, perlu ada regulasi yang memadai untuk memastikan bahwa proses pembayaran kembali penerusan pinjaman oleh BUMN tersebut dapat terlaksana dengan baik agar mengurangi risiko gagal bayar oleh BUMN.

Pengaturan pembayaran kembali penerusan pinjaman oleh Pemerintah kepada Pemerintah BUMN telah diatur dalam beberapa peraturan perundang- undangan yang ada secara sporadik, seperti: ${ }^{13}$

1. Peraturan Pemerintah Nomor 54 Tahun 2008 tentang Tata Cara Pengadaan dan Penerusan Pinjaman Dalam Negeri Oleh Pemerintah

2. Peraturan Pemerintah Nomor 10 Tahun 2011 tentang Tata Cara Pengadaan Pinjaman Luar Negeri dan Penerimaan Hibah

3. Peraturan Menteri Keuangan Nomor 108 Tahun 2016 tentang Tata Cara Penerusan Pinjaman Dalam Negeri dan Penerusan Pinjaman Luar Negeri kepada Badan Usaha Milik Negara dan Pemerintah Daerah sebagai aturan teknis pelaksanaannya.

Dalam peraturan perundang-undangan tersebut telah diatur berbagai hal, seperti prosedur pemberian pinjaman, syarat-syarat pemberian pinjaman, indikator-indikator pemberian pinjaman, dan sebagainya.

Dalam rangka pemberian pinjaman kepada BUMN, ternyata terdapat kekosongan hukum (rechtvacuum) terkait dengan jaminan untuk memastikan bahwa BUMN akan melakukan pembayaran terhadap pinjaman yang diberikan baginya. ${ }^{14}$ Jaminan ini menjadi penting dalam rangka untuk memastikan bahwa BUMN dapat membayar kembali pinjaman yang diberikan dan memastikan

11 M. Imron Rosyadi, “Keabsahan Penentuan Jaminan Aset Bumn Dalam Rangka Pemberian Pinjaman Oleh Pemerintah", Jurist-Diction 3 (2020): 428.

12 Ada dua pihak yang dapat memperoleh pinjaman, yaitu BUMN dan Pemerintah daerah. Selanjutnya lihat Ibid.

13 Ibid., hlm.429.

14 Wahyu Purnomo et.al.,"Analysis of Lawsuit against the Factual Action Which Conducted by Military after Law Number 30 the Year 2014 Concerning Government Administration”, Unram Law Review 4 (2019): 41. 
agar pinjaman tersebut dilaksanakan sesuai dengan prinsip efektif, efisien, serta akuntabilitas dalam rangka penyelenggaraan pemerintahan negara yang baik (good governance). Dalam rangka memastikan adanya upaya pemerintah untuk memberikan perlindungan hukum terhadap hal ini, maka diperlukan sebuah perlindungan hukum yang holistik. Menurut Philipus M. Hadjon, secara teoritis perlindungan hukum yang holistik terdiri dari dua, yaitu: ${ }^{15}$

1. Perlindungan hukum preventif.

2. Perlindungan hukum represif.

Perlindungan Hukum Preventif adalah perlindungan yang diberikan oleh pemerintah dengan tujuan untuk mencegah sebelum terjadinya pelanggaran. ${ }^{16}$ Hal ini terdapat dalam peraturan perundang-undangan dengan maksud untuk mencegah suatu pelanggaran serta memberikan rambu-rambu atau batasanbatasan dalam melakukan suatu kewajiban. Perlindungan Hukum Represif adalah perlindungan akhir berupa sanksi seperti denda, penjara, dan hukuman tambahan yang diberikan apabila sudah terjadi sengketa atau telah dilakukan suatu pelanggaran. ${ }^{17}$ Dalam konteks penelitian ini, akan dilakukan penelitian terkait upaya preventif dan represif bagi masyarakat dalam rangka mewujudkan tujuan Indonesia sebagai negara hukum dalam mengatasi permasalahan risiko gagal bayar dalam pemberian pinjaman kepada BUMN.

Berdasarkan latar belakang tersebut, maka rumusan masa yang dianalisa di dalam penelitian ini adalah Pertama, apa upaya preventif terhadap risiko gagal bayar dalam pemberian pinjaman kepada BUMN? Selanjutnya apa upaya represif terhadap risiko gagal bayar dalam pemberian pinjaman kepada BUMN?

\section{B. Metode Penelitian}

Penelitian ini adalah penelitian hukum. Penelitian hukum adalah penelitian yang meletakkan hukum sebagai sebuah bangunan sistem norma, yang terdiri dari asas-asas, norma, kaidah dari peraturan perundangan, putusan pengadilan, perjanjian serta doktrin (ajaran). ${ }^{18}$ Penelitian hukum ini dilakukan dengan mengkaji dan menganalisa peraturan perundang-undangan ataupun bahan hukum lain yang berkaitan dengan Upaya Pemerintah Untuk Meminimalisir Risiko Gagal Bayar Dalam Pemberian Pinjaman Kepada BUMN.

Penelitian ini menggunakan pendekatan peraturan perundang-undangan (statute approach) dan pendekatan konseptual (conceptual approach) Pendekatan perundang-undangan (statute approach) dilakukan dengan menelaah

15 Philipus M. Hadjon, Perlindungan Bagi Rakyat di Indonesia (Surabaya: PT.Bina Ilmu, 1987), hlm. 1-2.

16 Ibid.

17 Ibid.

18 Depri Liber Sonata, "Metode Penelitian Hukum Normatif dan Empiris: Karakteristik Khas Dari Metode Meneliti Hukum," Fiat Justitia Jurnal Ilmu Hukum 8 (2017): 25. 
semua peraturan perundang-undangan dan regulasi yang berkaitan dengan isu hukum yang ditangani, sehingga dapat diketahui ratio legis, dasar ontologis dan landasan filosofis pengaturan yang berkaitan tentang Upaya Pemerintah Untuk Meminimalisir Risiko Gagal Bayar Dalam Pemberian Pinjaman Kepada BUMN. ${ }^{19}$ Pendekatan konseptual (conceptual approach) merupakan Pendekatan konseptual beranjak dari pandanganpandangan dan doktrin-doktrin yang berkembang di dalam ilmu hukum. ${ }^{20}$ Pendekatan ini dilakukan dengan pemahaman atas konsep yang dikemukakan para ahli yang terdapat di berbagai literatur terutama yang terkait dengan Upaya Pemerintah Untuk Meminimalisir Risiko Gagal Bayar Dalam Pemberian Pinjaman Kepada BUMN.

\section{Pembahasan}

\section{Upaya Preventif untuk meminimalisir Risiko Gagal Bayar Dalam Pemberian Pinjaman kepada BUMN}

Jika melihat pengelompokan dalam ilmu hukum, maka sejatinya hukum keuangan negara tunduk pada hukum administrasi. ${ }^{21}$ Dengan dasar tersebut, maka dalam melakukan tindakan pemerintahan (bestuurhandeling), Menteri Keuangan yang notabene merupakan pengelola keuangan negara selalu harus tunduk pada aturan-aturan serta prinsipprinsip dalam hukum administrasi. Di sisi lain, walaupun hukum keuangan negara dominan berada dalam hukum publik, namun hukum keuangan negara tetap dapat tunduk hukum privat. Salah satu contoh hukum keuangan negara yang ada kaitannya dengan hukum privat adalah terkait tindakan pemerintah berupa pengelolaan BUMN. ${ }^{22}$

Tindakan Pemerintahan adalah tindakan atau perbuatan yang dilakukan oleh administrasi negara dalam melaksanakan tugas pemerintahan. ${ }^{23}$ Tindakan pemerintahan terdiri dari dua jenis, yaitu:

1. Tindakan faktual (feitelijke handelingen)

19 Zayanti Mandasari, "Politik Hukum Pengaturan Masyarakat Hukum Adat (Studi Putusan Mahkamah Konstitusi)," Jurnal Hukum IUS QUIA IUSTUM 2(2014): 231.

20 Zulfadli Barus, "Analisis Filosofis Tentang Peta Konseptual Penelitian Hukum Normatif Dan Penelitian Hukum Sosiologis,"Jurnal Dinamika Hukum 13(2014): 313.

21 Susanto, "Harmonisasi Hukum Makna Keuangan Negara dan Kekayaan Negara yang Dipisahkan pada Badan Usaha Milik Negara (BUMN) Persero" (makalah disampaikan pada Seminar Ilmiah Nasional Membangun Paradigma Kehidupan Melalui Multidisiplin Ilmu, Pamulang, Indonesia, Juli 2007)

22 Muhammad Djafar Saidi, Hukum Keuangan Negara Teori dan Praktik (Depok: Rajawali Press, 2017), hlm. 6.

23 Philipus M. Hadjon, Pengertian-Pengertian Dasar tentang Tindak Pemerintahan (Bestuurhandeling) (Surabaya: Penerbit Jumali, 1985), hlm. 1. 


\section{Tindakan hukum}

\section{(rechtshandelingen). ${ }^{24}$}

Menurut Philipus M. Hadjon, tindakan faktual adalah tindakan yang tidak menimbulkan konsekuensi yuridis, sedangkan tindakan hukum adalah tindakan yang dilakukan oleh Pemerintah yang memiliki konsekuensi yuridis. ${ }^{25}$ Konsekuensi yuridis yang dimaksud di sini adalah berkaitan dengan timbulnya hak dan kewajiban hukum. ${ }^{26}$ Hal serupa juga disampaikan oleh Ridwan HR. Menurutnya tindakan nyata adalah tindakan-tindakan yang tidak ada relevansinya dengan hukum dan oleh karenanya tidak menimbulkan akibatakibat hukum, sedangkan tindakan hukum adalah tindakan yang dimaksudkan menciptakan hak dan kewajiban (een rechtshandlingen is gericht op het scheppen van rechten of plichten). ${ }^{27}$
Tindakan hukum pemerintah dibagi dua, yaitu: ${ }^{28}$

1. tindakan hukum publik

$$
\text { (publiekrechtshandeling) }
$$

2. tindakan hukum privat

(privaterechtshandeling)

Terdapat pendapat yang menyatakan, bahwa tindakan hukum publik ini disebut juga sebagai tindakan hukum bersegi satu (eenzijdige rechtshandelingen), sementara tindakan hukum privat adalah tindakan hukum bersegi dua (tweezijdige publiek rechtshandelingen). ${ }^{29} \mathrm{Hal}$ ini didasarkan pada argumentasi, bahwa tindakan hukum publik ini bersifat sepihak dari pemerintah, sementara tindakan hukum privat melibat pihak lain yang notabene pemerintah dan pihak tersebut adalah sederajat.

Untuk lebih jelasnya tentang tindakan pemerintahan, dapat dilihat pada diagram di bawah ini:30

Gambar 1. Diagram tindakan Pemerintah

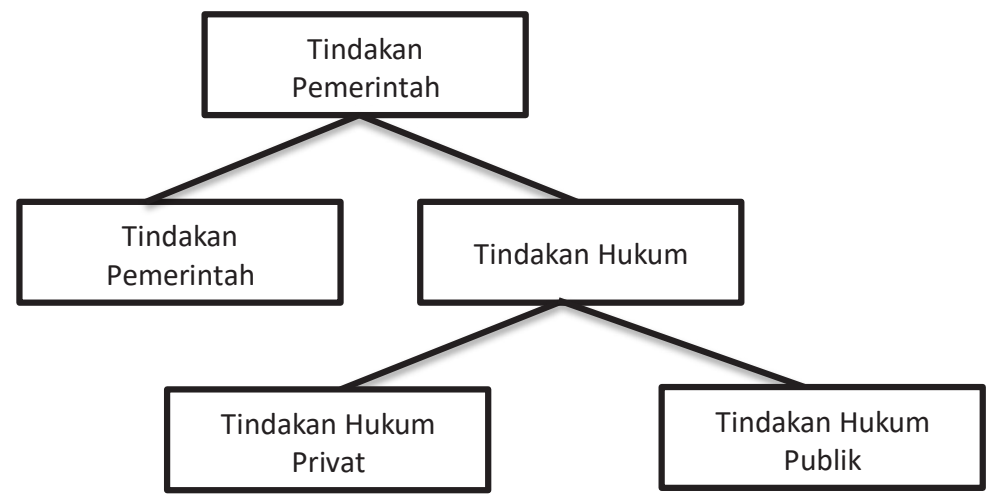

\footnotetext{
24 Philipus M. Hadjon, Op. Cit., hlm. 311.

25 Philipus M. Hadjon, et al., Pengantar Hukum Administrasi Indonesia (Jogjakarta: Gadjah Mada University Press, 2015), hlm. 87.

26 Ibid.

27 Ridwan HR, Hukum Administrasi Negara. (Jakarta: Rajawali Pers, 2006), hlm. 109.

28 Hero Prayogo," Hak Atas Tanah Dan Bangunan Rumah Adat Banjar Yang Berada Diatas Pinggiran Sungai Kota Banjarmasin" Tesis, Fakultas Hukum Universitas Airlangga, (2015):15.

29 Ibid., hlm.111.

30 Ibid., hlm. 311.
} 
Sebelumnya telah diulas, bahwa pengelolaan keuangan negara oleh Menteri Keuangan harus tunduk dan berdasarkan pada koridor dalam hukum administrasi. ${ }^{31} \mathrm{Hal}$ ini berarti, setiap tindakan pemerintah dalam melakukan pengelolaan keuangan negara harus tunduk dan patuh terhadap peraturan perundangundangan yang mengatur tentang keuangan negara yang notabene merupakan ranah hukum administrasi. Salah satu wujud pengelolaan keuangan negara, adalah pengelolaan pengadaan serta penerusan pinjaman pemerintah. Hal ini berarti, dua hal tersebut harus berdasarkan koridor hukum administrasi, sehingga konsekuensi yuridisnya adalah seluruh tindakan tersebut harus tunduk pada peraturan perundang-undangan dan asas-asas yang ada dalam hukum administrasi. Hal ini berarti, pemerintah yang notabene merupakan penguasa, dalam melaksanakan kewajiban berkaitan dengan pengelolaan pengadaan serta penerusan pinjaman pemerintah, tetap wajib melaksanakan tindakan pemerintahan berdasarkan hukum. Hal ini merupakan konsekuensi yuridis aras dianutnya asas legalitas (rechmatigheid) dalam hukum administrasi di Indonesia. ${ }^{32}$

Tindakan pemerintah dalam pemberian pinjaman kepada BUMN dapat dikategorikan sebagai suatu tindakan hukum. Hal ini didasarkan pada pendapat Philipus M. Hadjon dan Ridwan HR di atas, yang notabene tindakan pemerintah memberikan pinjaman kepada BUMN ini menimbulkan akibat hukum, yaitu lahirnya hak dan kewajiban bagi para pihak. Dalam hukum perjanjian, ketika terdapat hak, maka akan sekaligus akan timbul kewajiban, sehingga umumnya dalam suatu perjanjian tidak hanya satu pihak yang memiliki hak, sementara pihak yang lain memiliki kewajiban, namun para pihak saling memiliki hak dan kewajiban satu sama lain. Berikut hak dan kewajiban yang timbul dari para pihak yaitu:

Tabel 1. Tabel hak dan kewajiban BUMN dengan Pemerintah terkait Pemberian pinjaman

\begin{tabular}{|c|c|c|c|}
\hline Nomor & Pihak & Hak & Kewajiban \\
\hline 1 & BUMN & $\begin{array}{r}\text { memperoleh pinjaman dari } \\
\text { Pemerintah sesuai dengan } \\
\text { kontrak yang dibuat }\end{array}$ & $\begin{array}{r}\text { membayar pokok pinjaman dan } \\
\text { bunga }\end{array}$ \\
\hline 2 & Pemerintah & $\begin{array}{c}\text { memperoleh pembayaran } \\
\text { pokok pinjaman dan bunga }\end{array}$ & $\begin{array}{c}\text { Memberikan pinjaman kepada } \\
\text { BUMN sesuai dengan kontrak } \\
\text { yang dibuat }\end{array}$ \\
\hline
\end{tabular}

\footnotetext{
31 Yuli Indrawati, “Implikasi Regulasi Keuangan Negara bagi Pengelolaan Keuangan Otoritas Jasa Keuangan,” Jurnal Rechtsvinding 5 (2016): 206.

32 Ibid., hlm. 319.
} 
Terkait keabsahan perikatan yang lahir antara BUMN dengan pemerintah terkait perjanjian pemberian pinjaman ini umumnya memang mengacu ketentuan di dalam Pasal 1320 Burgerlijk Wetboek (BW), yaitu:33

1. sepakat mereka yang mengikatkan dirinya (de toestemming van degenen die zich verbinden);

2. kecakapan untuk membuat suatu perikatan (de bekwaamheid om eene verbintenis aan te gaan);

3. suatu hal tertentu (een bepaald onderwerp);

4. suatu kausa yang diperbolehkan (eene geoorloofde oorzaak).

Di dalam salah satu syarat keabsahan perjanjian tersebut, dapat dilihat bahwa syarat keempat adalah syarat objektif yang mengatur, bahwa yang dimaksud sebab halal berarti kausa perjanjian tersebut tidak boleh dilarang oleh Undang-Undang atau bila sebab itu bertentangan dengan kesusilaan atau dengan ketertiban umum. ${ }^{34}$ Dalam konteks pemberian pinjaman dari Pemerintah kepada BUMN, maka harus juga melihat kepada aturan khusus (lex specialis) terkait hal ini yang notabene ada dalam Peraturan Pemerintah Nomor 54 Tahun 2008 tentang Tata Cara
Pengadaan dan Penerusan Pinjaman dalam Negeri oleh Pemerintah. Hal ini menunjukan, bahwa selain tunduk pada perjanjian dan pengaturan terkait hukum privat, namun Pemerintah juga harus tunduk peraturan perundang-undangan dalam hukum publik. Hal ini menunjukan, bahwa dalam melakukan tindakan pemerintahan, walaupun sebagai badan hukum publik, organ pemerintah dapat juga melakukan tindakan hukum keperdataan terkait dengan perjanjian dengan pihak lain.

Dengan dasar kedudukan BUMN dan Pemerintah adalah para pihak yang membuat perjanjian, maka Pemerintah yang notabene pasti berkedudukan sebagai pemegang saham mayoritas BUMN, dalam hal ini tetap bertindak sebagai kreditur, bukan bertindak dalam rangka Pemilik BUMN. Dengan kondisi seperti ini, maka seharusnya pemberian pinjaman pemerintah kepada BUMN bukan merupakan suatu bentuk penanaman modal pemerintah yang akan mengubah persentase kepemilikan saham pemerintah terhadap BUMN. ${ }^{35}$ Hubungan hukum yang terjadi tetap adalah perjanjian pinjam-meminjam antara pemberi pinjaman dan penerima pinjaman.

33 Xavier Nugraha, John Eno Prasito Putra, Krisna Darari Hamonangan Putra, “Analisa Daluarsa Gugatan Pembatalan Perjanjian Akibat Adanya Penyalahgunaan Keadaan (Misbruik Van Omstandigheiden)", Galuh Justisi 8 (2020): 54-62.

34 Ibid.

35 M. Imron Rosyadi," Keabsahan Penentuan Jaminan Aset Bumn Dalam Rangka Pemberian Pinjaman Oleh Pemerintah", Skripsi, Fakultas Hukum Universitas Airlangga, (2019):40. 
Dalam rangka memberikan pinjaman dari Pemerintah kepada BUMN, meskipun BUMN notabene mayoritas dimiliki oleh negara, namun Pemerintah tidak bisa sembarangan memberikan pinjaman. Ada indikator yang harus diperhatikan oleh pemerintah, sebelum memberikan pinjaman kepada BUMN. Indikator-indikator ini sejatinya merupakan upaya preventif awal dari Pemerintah dalam memberikan pinjaman kepada BUMN. Dengan memperhatikan faktor-faktor yang ada dalam memberikan pinjaman kepada BUMN ini, maka sejatinya merupakan langkah awal dari upaya preventif terhadap gagal bayarnya BUMN. Faktor-faktor ini, seharusnya diperhatikan, mulai dari tahap perencanaan sampai tahap evaluasi dan pengawasan terhadap pemberian pinjaman kepada BUMN. ${ }^{36} \mathrm{Hal}$ ini bertujuan, agar setiap proses pemberian pinjaman dari BUMN kepada pemerintah tersebut benar-benar berhati-hati. Indikator-indikator tersebut antara lain: 37

a. Prudensial, dimaksudkan untuk tetap menjaga utang dalam batas yang aman (27-29\% terhadap PDB) dan mengusahakan agar rasio utang terus dapat ditekan dan menurun dalam jangka waktu menengah;

b. Biaya utang minimum, mendorong efisiensi biaya utang pada tingkat risiko yang terkendali serta mendukung kesinambungan fiskal;

c. Produktivitas, utang digunakan untuk kegiatan produktif untuk dapat mencapai target pembangunan, seperti pembiayaan investasi dalam rangka melakukan percepatan dalam pembangunan infrastruktur;

d. Keseimbangan, menjaga agar komposisi utang tetap terjaga dalam batas terkendali sebagai upaya pengendalian risiko, serta menjaga keseimbangan ekonomi makro.

Setelah memenuhi indikatorindiaktor yang ada, maka Upaya preventif Pemerintah berikutnya untuk menghindari terjadinya gagal bayar diwujudkan dengan penerapan persyaratan yang ketat bagi BUMN calon penerima penerusan pinjaman dari Pemerintah. Berdasarkan Pasal 15 ayat (2) Peraturan Pemerintah Nomor 54 Tahun 2008 tentang Tata Cara Pengadaan dan Penerusan Pinjaman dalam Negeri oleh Pemerintah, untuk penerusan pinjaman dalam dan negeri, BUMN sebagai Calon Penerima Penerusan Pinjaman harus memenuhi syarat paling sedikit:
a. Memiliki laba bersih selama 2 (dua) tahun terakhir;
b. Tidak mempunyai tunggakan atas

\footnotetext{
36 Atmaja, Arifin Soerja, Keuangan Publik dalam Perspektif Hukum: Teori, Praktik, dan Kritik (Jakarta: Badan Penerbit Fakultas Hukum Indonesia, 2005), hlm. 20.

37 Direktorat Jenderal Anggaran, Informasi APBN 2018 (Jakarta: Kementerian Keuangan, 2018), hlm. 33.
} 
pengembalian pinjaman yang berasal dari pemerintah;

c. Mendapat persetujuan dari organ perusahaan sesuai dengan Anggaran Dasar BUMN yang bersangkutan; dan

d. Memiliki laporan keuangan yang telah diaudit oleh auditor dan dinyatakan wajar tanpa pengecualian selama 3 (tiga) tahun terakhir sesuai ketentuan Peraturan Perundang-undangan di bidang BUMN.

Dalam Penjelasan Umum Peraturan Pemerintah Nomor 54 Tahun 2008 tentang Tata Cara Pengadaan dan Penerusan Pinjaman bagi Perusahaan Dalam Negeri (PMDN) terdapat beberapa Persyaratan BUMN sebagai Calon Penerima pinjaman. Terdapat beberapa kriteria, yaitu: ${ }^{38}$

a. Kredibilitas terkait tingkat kepercayaan terhadap kinerja BUMN.

b. Arus Kas untuk mengetahui adanya pengaruh kas dari kegiatan operasi, kegiatan investasi, serta kegiatan pendanaan, serta kenaikan atau penurunan bersih dalam kas suatu perusahaan dalam periode waktu tertentu

c. Likuiditas

kemampuan perusahaan untuk dapat membayar kewajiban jangka pendeknya

\section{d. Solvabilitas}

kemampuan perusahaan untuk dapat membayar atas semua kewajibannya

e. Rentabilitas

kemampuan perusahaan untuk dapat menghasilkan laba selama periode tertentu dari aktiva tertentu.

Kriteria yang sama, juga diberikan bagi BUMN Calon Penerima Pinjaman Luar Negeri seperti diatur dalam PP Nomor 10 Tahun 2011 tentang Tata Cara Pengadaan Pinjaman Luar Negeri dan Penerimaan Hibah.

Setelah pengajuan persyaratan calon penerima penerusan pinjaman, hal berikutnya adalah adanya penilaian kepada BUMN yang akan menerima pinjaman dari Pemerintah. Di dalam Peraturan Menteri Keuangan Nomor 108/PMK.05/2016 tentang Tata Cara Penerusan Pinjaman Dalam Negeri dan Penerusan Pinjaman Luar Negeri kepada Badan Usaha Milik Negara atau Pemerintah Daerah, diatur bahwa Direktur Jenderal Perbendaharaan c.q. Direktur Sistem Manajemen Investasi berwenang melakukan penilaian kelayakan, yang meliputi: ${ }^{39}$

a. kebutuhan riil pembiayaan;

b. kemampuan membayar kembali;

c. batas maksimum kumulatif pinjaman;

d. kemampuan penyerapan PPDN/ PPLN;

38 M. Imron Rosyadi Op.cit., hlm.48.

39 Ibid. 
e. risiko PPDN/PPLN;

f. hasil evaluasi atas studi kelayakan kegiatan; dan

g. kesesuaian dengan kebijakan Pemerintah berdasarkan peraturan perundang- perundangan.

Setelah proses penilaian kelayakan dilakukan, maka hutang dapat diserahkan. Setelah hutang diserahkan, maka proses selanjutnya yang merepresentasikan perlindungan hukum preventif adalah adanya pengawasan dalam pelaksanaan pemberian hutang ini. Dalam peraturan perundang-undangan kewenangan tersebut diberikan kepada Menteri Keuangan (melalui Direktur Jenderal Perbendaharaan) untuk melakukan pemantauan serta evaluasi terhadap penarikan, penyaluran, penyerapan, dan pembayaran kembali PPDN/PPLN kepada BUMN. Direktur Jenderal Perbendaharaan juga mempunyai wewenang untuk melakukan pengawasan serta evaluasi terhadap pemberian pinjaman Pemerintah kepada BUMN.

Setelah adanya pengawasan, hal terakhir nantinya akan ada laporan pertanggungjawaban yang harus disampaikan. Hal ini untuk memastikan, bahwa pinjaman yang diberikan penggunaannya sudah tepat. Hal ini juga bertujuan, agar kedepannya tidak ada masalah hukum yang muncul dalam pemberian pinjaman tersebut, seperti adanya korupsi. Direksi BUMN

40 Ibid. yang pada akhirnya akan memiliki tanggung jawab untuk menyampaikan laporan kepada Direktur Jenderal Perbendaharaan. Laporan-laporan tersebut meliputi:40

a. laporan triwulanan pelaksanaan kegiatan yang dibiayai dengan PPDN/PPLN;

b. Iaporan triwulanan realisasi PPDN/ PPLN;

c. laporan keuangan yang telah diaudit; dan

d. laporan lain yang ditentukan dalam Perjanjian PPDN/Perjanjian PPLN.

Berikut diagram proses pemberian pinjaman kepada BUMN yang mereprentasikan perlindungan hukum preventif terkait gagal bayarnya BUMN kepada Pemerintah:

Gambar 2. Diagram proses pemberian pinjaman kepada BUMN

\begin{tabular}{|c|c|}
\hline $\begin{array}{c}\text { Memperhatikan } \\
\text { indikator- } \\
\text { indikator } \\
\text { sebelum }\end{array}$ & $\begin{array}{c}\text { Menerapkan } \\
\text { Syarat-syarat } \\
\text { yang ketat } \\
\text { kepada BUMN }\end{array}$ \\
\hline
\end{tabular}
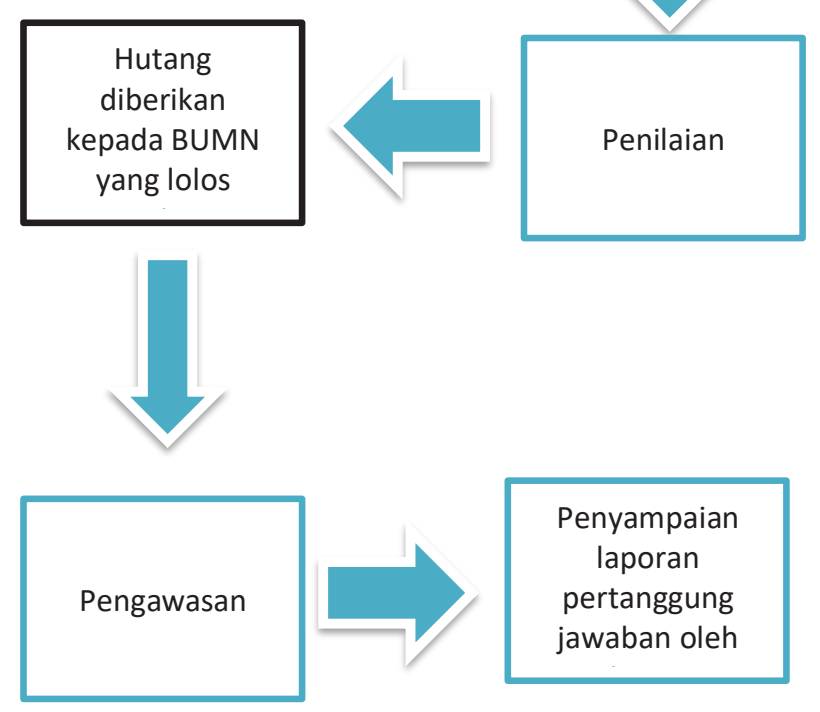

Penyampaian laporan pertanggung jawaban oleh 
2. Upaya Represif untuk meminimalisir Risiko Gagal Bayar dalam Pemberian Pinjaman kepada BUMN

Membaca judul sub bab ini, seolah-olah terdapat contradictio in terminis, karena upaya represif yang notabene adalah upaya yang digunakan setelah adanya pelanggaran, justru seolah-olah merupakan upaya preventif untuk meminimalisir risiko gagal bayar dalam pemberian pinjaman kepada BUMN. Dalam perkembangan hukum modern, adanya pandangan perlindungan hukum represif yang notabene adalah sanksi, dianggap sebagai upaya untuk mencegah adanya pelanggaran. Hal ini didasarkan, karena:

1. Sanksi untuk memberikan ketakutan

Adanya sanksi ini dianggap sebagai upaya untuk mencegah adanya pelanggaran, karena melalui sanksi akan menciptakan ketakutan bagi orang yang akan melanggar. Pemikiran ini berlandaskan pada asas presumptio iures de iure, yang berarti setiap orang dianggap tahu hukum, sehingga berkonsekuensi setiap orang dianggap akan paham sanksi yang akan muncul atas pelanggaran yang akan dilakukannya. ${ }^{41}$ Dengan dipahaminya sanksi yang ada di dalam peratutan perundang-undangan, akan membuat orang ketakutan, sehingga berhatihati untuk tidak melakukan pelanggaran.

2. Sanksi sebagai pertimbangan ekonomis sebelum pelanggaran Manusia merupakan homo economicus yang notabene akan selalu menggunakan perhitungan untung dan rugi (compensatio lucri cum domno). ${ }^{42}$ Dengan dasar demikian, tidak menutup kemungkinan terdapat orang yang secara sengaja melakukan pelanggaran dengan pertimbangan, bahwa keuntungan yang diperoleh lebih besar daripada potensi sanksi yang akan muncul ketika dia melakukan pelanggaran. Michael Trebilock menyebutkan hal yang serupa, bahwa man is a rational actor and immoral yang notabene akan membuat kalkulasi mengenai keuntungan dan kerugian (cost and benefiti analysis) dari kejahatan yang (akan) dilakukannya. ${ }^{43}$ Dengan dasar pemikiran

41 Dewi Sukmaningsih," Role of Documentation and Legal Information Network (JDIH) Efforts in Fulfillment of Human Rights", Jurnal Daulat Hukum 1 (2018): 371.

42 Rodrigo da Guia Silva, "Compensatio lucri cum damno no direito brasileiro: estudo a partir da jurisprudência do Superior Tribunal de Justiça sobre o pagamento do DPVAT", Revista Brasileira de Direito Civil 16(2018): 140.

43 Romli Atmasasmita dan Kodrat Wibowo, Analisis Ekonomi Mikro tentang Hukum Pidana Indonesia (Kencana: Jakarta,2016), hlm.78. 
tersebut, dengan dibentuknya sanksi yang lebih berat daripada keuntungan yang dapat diperoleh, maka akan mencegah adanya seseorang melakukan pelanggaran, karena keuntungan yang diperoleh akan lebih kecil daripada sanksi yang akan dia terima. Adanya persesuaian antara sanksi dengan pelanggaran ini oleh Jeremy Bentahm disebut sebagai felicific calculus. ${ }^{44}$

Dalam hukum administrasi, dikenal adanya pengenaan sanksi terhadap tindakan-tindakan yang bertentangan dengan peraturan perundangundangan. Bentuk sanksi yaitu: 45

a. paksaan pemerintah (bestuurdwang);

b. penarikan kembali keputusan yang menguntungkan;

c. pengenaan denda administratif; serta

d. pengenaan uang paksa oleh Pemerintah (dwangsom).

Sanksi administrasi lebih ditujukan kepada perbuatan pelanggarannya, agar perbuatan tersebut dihentikan, dan bersifat reparatoir, yang berarti memulihkan pada keadaan sebelum terjadi pelanggaran (restitutio in integrum). ${ }^{46}$ Tujuan sanksi administrasi bukan untuk menghukum atau memberikan nestapa bagi pelanggarnya layaknya sanksi dalam hukum pidana. Pemberian sanksi administrasi dimaksudkan agar keadaan menyimpang tersebut dapat dihentikan dan kembali lagi dalam keadaan sebagaimana mestinya.

Adapun upaya represif yang diatur dalam ketentuan peraturan perundang-undangan dalam rangka pemberian pinjaman Pemerintah kepada BUMN terdapat dua macam, yaitu:47

1. Pengenaan denda kepada BUMN yang tidak mematuhi kewajiban penyampaian laporan keuangan kepada Menteri Keuangan.

Dalam Pasal 48 ayat (3) PMK Nomor 108 Tahun 2016, disebutkan bahwa: "BUMN/Pemda yang tidak memenuhi ketentuan sebagaimana dimaksud dalam Pasal 44 dan Pasal 45, dikenakan denda sebesar Rp 1.000.000,00 (satu juta rupiah) setiap bulan paling banyak $\mathrm{Rp}$ 24.000.000,00 (dua puluh empat juta rupiah)."

2. Pengenaan denda kepada BUMN yang terlambat melakukan pembayaran kembali pinjaman ke Pemerintah sesuai waktu yang ditentukan dalam Naskah Perjanjian Penerusan Pinjaman Luar Negeri.

Pemberian sanksi untuk jenis pelanggaran seperti ini ialah denda administrasi yang besarannya diatur

\footnotetext{
44 Jeremy Bentham, An Introduction to the Principles of Morals and Legislation (New York: Hafner Publishing Co., 1948) hlm. 21

45 Philipus M. Hadjon, Op. Cit., hlm.237.

46 Ibid., hlm. 239.

47 M. Imron Rosyadi Op.cit.,hlm.51.
} 
dalam Naskah Perjanjian Penerusan PDN/PLN.

Bentuk sanksi lain yang dapat dikenakan ialah sanksi pidana. Sanksi pidana merupakan salah satu bentuk upaya pemaksaan hukum (law enforcement) terhadap pihak pelanggar yang membawa akibat hukum yang terkait dengan kemerdekaan pribadi (berupa pidana penjara, kurungan, dan pengenaan denda) dari pelanggar yang bersangkutan. ${ }^{48}$ Dalam hukum pidana dan hukum administrasi memang memiliki Hubungan yang kuat dan saling terkait. Hal ini ditunjukkan oleh adanya pelanggaran terhadap hukum administrasi dapat ditegakkan dengan sanksi pidana. Hal ini dikenal dengan istilah "in cauda venenum" ("ada racun di ekor atau buntut" : sanksi (hukum) pidana adalah racunnya hukum administrasi).

Dalam konteks pembayaran pinjaman dari BUMN kepada Pemerintah, apabila pembayaran kembali dana pinjaman kepada Pemerintah tidak dapat dilaksanakan oleh BUMN dengan indikasi adanya penyalahgunaan penggunaan dana secara pribadi oleh pejabat yang berwenang secara melawan hukum yang berpotensi menimbulkan kerugian keuangan negara, maka sanksi pidana dapat diterapkan. Terhadap jenis pelanggaran seperti ini, maka dapat diterapkan sanksi pidana sebagaimana diatur dalam Undang-Undang Nomor 31 Tahun 1999 jo. Undang-Undang Nomor 20 Tahun 2001 tentang Pemberantasan Tindak Pidana Korupsi.

Penerapan sanksi pidana kepada pelanggar aturan tidak dapat menggunakan mekanisme besturdwaang oleh Pemerintah secara langsung, melainkan harus melalui proses peradilan. Penegakan sanksi pidana dilaksanakan dengan cara penggunaan "due process of law" yang telah ditentukan di dalam kaidah hukum acara pidana dan pengenaan sanksi itu hanya dapat dinyatakan dalam suatu putusan hakim pidana. ${ }^{49}$

Baik sanksi pidana maupun sanksi administrasi mempunyai tujuan sendiri-sendiri dalam penegakannya, namun sifatnya adalah represif atau setelah keadaan yang dilarang terjadi. Dengan kata lain, sanksi ini sebagai respon pemerintah ketika terjadi pelanggaran dalam pelaksanaan pembayaran kembali pinjaman oleh BUMN kepada Pemerintah. Berdasarkan uraian tersebut, tampak bahwa upaya represif Pemerintah yang telah diatur dalam ketentuan peraturan perundang-undangan dalam penge-lolaan pemberian pinjaman kepada BUMN kurang efektif untuk dapat memastikan hak masing-masing pihak, terutama hak kreditur, dalam hal ini

48 Philipus M. Hadjon, Op. Cit.,hlm254.

49 Ibid., hlm. 255. 
Pemerintah, terlindungi ketika terjadi wanprestasi dari BUMN penerima pinjaman. Upaya represif berupa penerapan sanksi administrasi dan sanksi pidana baru dapat diterapkan setelah terjadinya pelanggaran. Hal ini berbeda dengan upaya preventif yang bertujuan untuk melakukan pencegahan terhadap adanya kemungkinan pelanggaran. Dengan dasar demikian, maka upaya preventif Pemerintah harus dioptimalkan untuk menjaga agar risiko gagal bayar pembayaran kembali pinjaman Pemerintah kepada BUMN dapat terkendali. Mengingat instrumen penerapan sanksi yang diberikan peraturan perundang-undangan belum cukup kuat untuk mengurangi risiko gagal bayar yang terjadi dalam pemberian pinjaman Pemerintah kepada BUMN, sehingga upaya-upaya preventif harus lebih diutamakan.

\section{Penutup}

Upaya preventif yang dapat dilakukan oleh Pemerintah untuk meminimalisir risiko gagal bayar dalam pemberian pinjaman kepada BUMN adalah dengan menerapkan prinsip kehatihatian dalam setiap proses pengelolaan pemberian pinjaman dan menggunakan kewenangan pemerintah yang ada. Penerapan prinsip kehati-hatian dalam pemberian pinjaman kepada BUMN tersebut termanifestasi dengan cara memberikan peminjaman secara transparan, akuntabel, efektif dan efisien.
Berkaitan dengan penggunaan wewenang pemerintah untuk meminimalisir risiko gagal bayar dalam pemberian pinjaman kepada BUMN adalah dengan mengawasi serta evaluasi terhadap pelaksanaan program pemberian pinjaman kepada BUMN. Dengan adanya upaya preventif ini, diharapkan dapat mencegah adanya risiko gagal bayar dalam pemberian pinjaman kepada BUMN.

Upaya represif yang dapat dilakukan oleh pemerintah apabila terjadi risiko gagal bayar dalam pemberian pinjaman kepada BUMN adalah melalui pengenaan sanksi administrasi dan/atau pidana. Pengenaan sanksi administrasi dan/atau pidana ini bukan berarti bersifat absolut ketika terjadi gagal bayar dalam pemberian pinjaman kepada BUMN. Terdapat keadaan-keadaan khusus, barulah sanksi represif ini dapat dilaksanakan. Berkaitan dengan sanksi administrasi yang dapat diterapkan oleh Pemerintah, misal ialah pengenaan denda kepada BUMN yang tidak mematuhi kewajiban penyampaian laporan keuangan kepada Menteri Keuangan dan pengenaan denda kepada BUMN yang terlambat melakukan pembayaran kembali pinjaman ke Pemerintah. Berkaitan dengan sanksi pidana akan diterapkan, apabila pembayaran kembali dana pinjaman kepada Pemerintah tidak dapat dilaksanakan oleh BUMN dengan indikasi adanya penyalahgunaan penggunaan dana secara pribadi oleh pejabat yang berwenang secara 
melawan hukum yang berpotensi menimbulkan kerugian keuangan negara.

Diharapkan ke depannya, terdapat pengaturan dalam peraturan perundangundangan yang mengatur kewenangan Pemerintah dalam menentukan aset BUMN sebagai jaminan dalam pemberian pinjaman kepada BUMN. Dengan adanya pengaturan tersebut, akan memberi legitimasi Pemerintah dalam bertindak, sehingga keabsahan penentuan jaminan aset BUMN tersebut dapat dipenuhi. Pemerintah dalam hal ini Kementerian Keuangan sebaiknya memaksimalkan penggunaan upaya-upaya preventif dalam pelaksanaan pemberian pinjaman kepada BUMN. Pengawasan serta evaluasi terhadap laporan perkembangan pelaksanaan penerusan pinjaman dari BUMN harus dapat dimaksimalkan untuk mengurangi resiko kegagalan pembayaran kembali pinjaman oleh BUMN. 


\section{DAFTAR PUSTAKA}

\section{A. Buku}

Atmaja, Arifin Soeria, Keuangan Publik dalam Perspektif Hukum : Teori, Praktik, dan Kritik, (Jakarta: Badan Penerbit Fakultas Hukum Indonesia, 2005).

Atmasasmita, Romli dan Kodrat Wibowo, Analisis Ekonomi Mikro tentang Hukum Pidana Indonesia (Kencana: Jakarta, 2016)

Bentham, Jeremy, An Introduction to the Principles of Morals and Legislation (New York: Hafner Publishing Co., 1948)

Bohari, Hukum Anggaran Negara, (Jakarta: Rajawali Press, 1995).

BPK RI, Jurnal Tata Kelola \& Akuntabilitas Keuangan Negara, (Jakarta: BPHN Puslitbang, 2010).

Dicey, A.V., Introduction to the Study of the Law of the Constitution, (London: The Macmillan Press, 1979).

Direktorat Jenderal Anggaran, Informasi APBN 2018 (Jakarta: Kementrian Keuangan, 2018).

Fakhurohman, Dian Aminudin dan Sirajudin, Memahami Keberadaan Mahkamah Konstitusi di Indonesia (Bandung: Citra Aditya Bakti, 2004).

Hadjon, Philipus M., et al., Pengantar Hukum Administrasi Indonensia, (Jogjakarta: Gadjah Mada University Press, 2015).

Hadjon, Philipus M., Pengertian-Pengertian Dasar tentang Tindak Pemerintahan (Bestuurhandeling) (Surabaya: Penerbit Jumali, 1985).

Hadjon, Phlipus M., Perlindungan bagi Rakyat di Indonesia, (Surabaya: PT. Bina Ilmu, 1987).

Hartini, Rahayu, BUMN Persero, Konsep Keuangan Negara dan Hukum Kepailitan di Indonesia, (Malang: Setara Press, 2017).

HR, Ridwan, Hukum Administrasi Negara. (Jakarta: Rajawali Pers, 2006.

Ilmar, Aminuddin, Hak Menguasi Negara Dalam Privatisasi BUMN (Jakarta: Kharisma Putra Utama, 2012).

Saidi, Muhammad Djafar, et. al., Hukum Keuangan Negara Teori dan Praktik, (Depok: Rajawali Press, 2017).

\section{B. Makalah/Artikel/Prosiding/Hasil Penelitian}

Barus, Zulfadli, “Analisis Filosofis Tentang Peta Konseptual Penelitian Hukum Normatif Dan Penelitian Hukum Sosiologis,"Jurnal Dinamika Hukum (2014).

Harsono, "Kerjasama antara Perusahaan Negara, Swasta, dan Koperasi dalam rangka Menyukseskan Pembangunan Ekonomi di Indonesia" (Pidato Pengukuhan dalam Penerimaan Jabatan Guru Besar Universitas Brawijaya, Malang, Indonesia, 1986). 
Indrawati, Yuli, "Implikasi Regulasi Keuangan Negara bagi Pengelolaan Keuangan Otoritas Jasa Keuangan," Jurnal Rechtsvinding (2016).

Mandasari, Zayanti, "Politik Hukum Pengaturan Masyarakat Hukum Adat (Studi Putusan Mahkamah Konstitusi)," Jurnal Hukum IUS QUIA IUSTUM (2014).

Nugraha, Xavier John Eno Prasito Putra, Krisna Darari Hamonangan Putra, "Analisa Daluarsa Gugatan Pembatalan Perjanjian Akibat Adanya Penyalahgunaan Keadaan (Misbruik Van Omstandigheiden)", Galuh Justisi 8 (2020)

Prayogo, Hero," Hak Atas Tanah Dan Bangunan Rumah Adat Banjar Yang Berada Diatas Pinggiran Sungai Kota Banjarmasin" Tesis, Fakultas Hukum Universitas Airlangga, (2015)

Purnomo, Wahyu et.al.,"Analysis of Lawsuit against the Factual Action Which Conducted by Military after Law Number 30 the Year 2014 Concerning Government Administration", Unram Law Review (2019).

R., Ibrahim, “Landasan Filosofis dan Yuridis Keberadaan BUMN: Sebuah Tinjauan," Jurnal Hukum Bisnis (2007).

Rosyadi, M. Imron, "Keabsahan Penentuan Jaminan Aset Bumn Dalam Rangka Pemberian Pinjaman Oleh Pemerintah", Jurist-Diction 3 (2020)

Rosyadi, M. Imron," Keabsahan Penentuan Jaminan Aset Bumn Dalam Rangka Pemberian Pinjaman Oleh Pemerintah", Skripsi, Fakultas Hukum Universitas Airlangga, (2019).

Silva, Rodrigo da Guia, "Compensatio lucri cum damno no direito brasileiro: estudo a partir da jurisprudência do Superior Tribunal de Justiça sobre o pagamento do DPVAT", Revista Brasileira de Direito Civil 16(2018).

Sonata, Depri Liber, "Metode Penelitian Hukum Normatif dan Empiris: Karakteristik Khas Dari Metode Meneliti Hukum," Fiat Justitia Jurnal Ilmu Hukum (2017).

Susanto, "Harmonisasi Hukum Makna Keuangan Negara dan Kekayaan Negara yang Dipisahkan pada Badan Usaha Milik Negara (BUMN) Persero" (makalah disampaikan pada Seminar Ilmiah Nasional Membangun Paradigma Kehidupan Melalui Multidisiplin IImu, Pamulang, Indonesia, Juli 2007).

Yusroni, Nanang dan Restiysnto, Dumadi Tri, “Privatisasi Badan Usaha Milik Negara (BUMN), Eksistensi, Dan Kinerja Ekonomi Nasional Dalam Sistem Ekonomi Pasar," Jurnal Ekonomi dan Bisinis (2007). 


\section{BIODATA PENULIS}

Penulis pertama bernama Xavier Nugraha, seorang paralegal di sebuah kantor hukum di Surabaya. Xavier menyelesaikan studinya di jenjang Strata Satu (S-1) di Fakultas Hukum, Universitas Airlangga, Surabaya pada 2019 dengan mendapat penghargaan sebagai Wisudawan TerbaikFakultas Hukum, Universitas Airlangga dan Wisudawan Berprestasi Universitas Airlangga. Sejak duduk di bangku kuliah, Xavier telah mengikuti dan menjuarai berbagai kompetisi, seperti Juara 1 Debat Mahkamah Konstitusi Regional Timur 2019, Juara 1 Marvelaw UNNES Competition 2018, Juara 2 Debat Mochtar Riady Legal Fair 2018, dan sebagainya. Xavier juga telah menjadi pembicara pada tingkat nasional dan internasional, seperti Speaker International Law Conference 2019, $5^{\text {th }}$ International Conference on Contemporary Social and Political Affairs (ICoCSPA) 2019, $2^{\text {nd }}$ International Conference on Islamic Studies, International Conference of State Finance and Accountability (InCSFA), dan sebagainya. Xavier, juga telah menghasilkan 26 artikel di jurnal bidang hukum, yang terdiri dari jurnal nasional dan internasional, seperti Rekonstruksi Batas Usia Minimal Perkawinan Sebagai Bentuk Perlindungan Hukum Terhadap Perempuan (Analisa Putusan MK No. 22/Puu-Xv/2017), Pemilihan Kepala Daerah Oleh Dewan Perwakilan Rakyat Daerah: Sebuah Komparasi Dengan Pemilihan Secara Langsung Oleh Rakyat, Analysis on Non-Muslim Heir Position Towards the Inheritance of Muslim Testator in Indonesia, Hak Konstitusional Lembaga Kepresidenan Dalam Penolakan Pengesahan RUU APBN Oleh DPR, The Involvement of Soes in Procurement of Goods or Services in Indonesia: Is It Ethical? dan sebagainya.

Penulis kedua bernama Patricia Inge Felany sedang menempuh pendidikan sarjana hukum pada Universitas Airlangga, pernah berkolaborasi dengan Nina Amelia Novita Sari, Ezra Tambunan dan Xavier Nugraha dalam menuliskan Jurnal UPH Law Review dengan judul Implikasi Penafsiran Hak Menguasai Negara oleh Mahkamah Konstitusi terhadap Politik Hukum Agraria pada Pulau-Pulau Kecil di Indonesia.

Penulis ketiga adalah M Imron Rosyadi seorang mantan mahasiswa FH UNAIR 2015 yang lulus pada tahun 2019. Sekarang penulis bekerja pada Kementerian Keuangan Republik Indonesia. 